\title{
ECONOMIC ASSESSMENT OF THE DEPENDENCE OF AN ORGANIZATION'S COMPETITIVENESS ON REPUTATION CAPITAL
}

\author{
AIDAROVNA-KAMALOVA Alina ${ }^{1}$, \\ LENAROVNA-KURBANGALIEVA Dinara ${ }^{2}$ \\ ${ }^{1}$ Institute of Management, Economics and Finance, Department of General Management, Kazan Federal University \\ (RUSSIA) \\ ${ }^{2}$ Institute of Management, Economics and Finance, Department of General Management, Kazan Federal University \\ (RUSSIA) \\ Emails: alina.kamalova007@list.ru; dhasanova@list.ru
}

\begin{abstract}
There are many interpretations of the term reputation'. Most authors refer to the general definition of reputation, considering reputation (fr., From lat. 'Reputatio' reflection, reasoning) as "a common opinion about the merits and demerits of someone, smth". The nature and essence of the business reputation of the enterprise are multifaceted and depending on the discipline studied, each researcher has his own interpretation. As well as the very concept of reputation for various fields of science is interpreted differently, the methods of assessment differ. In this article, we analyze the Economic Assessment of the Dependence of an Organization's Competitiveness on Reputation Capital and consider the tools that form reputation capital and methods for assessing it. Based on a review of existing factors in the formation of reputation capital and valuation methods, we will be able to identify key focuses for further research. In the course of the analysis carried out in the work, we found that the formation internal factors of reputation capital play a significant role in ensuring competitiveness, namely, the organization's personnel, its corporate culture.
\end{abstract}

Keywords: reputation, corporate reputation, methods, internal environment

JEL:M14

UDC: 005.332:347.715

005.336.6:334.7

658:339.137.2

COBISS.SR-ID 28649481

\section{Introduction}

There are many interpretations of the term reputation. Most authors refer to the general definition of reputation, considering reputation (fr., From lat. 'Reputatio' reflection, reasoning) as "a common opinion about the merits and demerits of someone, smth".

The nature and essence of the business reputation of the enterprise are multifaceted and depending on the discipline studied, each researcher has his own interpretation.

The concept of business reputation is supplemented by interpretations and emphasis, depending on the discipline that shows interest in this phenomenon (Table 1 shows the 
interpretation of the definition of "reputation" depending on six areas of knowledge, according to Charles Fombrun and Key Van Rila) [3].

Table 1. Definition of "goodwill" in various disciplines Definition

\begin{tabular}{|c|c|}
\hline Marketing & $\begin{array}{l}\text { Reputation as a cognitive perception of the company by stakeholders, forming their position } \\
\text { in relation to the company and willingness to support. }\end{array}$ \\
\hline Economy & $\begin{array}{l}\text { Reputation as signals generated by a company about its key advantages in order to increase } \\
\text { competitiveness. }\end{array}$ \\
\hline Management & $\begin{array}{l}\text { Reputation as a barrier to customer mobility. In other words, it keeps customers and provides } \\
\text { profit for the company. }\end{array}$ \\
\hline Sociology & $\begin{array}{l}\text { Reputation as a public assessment of an organization's activities relative to norms and } \\
\text { expectations. Sociologists emphasize the multiple nature of the actors involved in the process } \\
\text { of building a reputation, and their interconnectedness. }\end{array}$ \\
\hline $\begin{array}{l}\text { Economy of the } \\
\text { enterprise }\end{array}$ & $\begin{array}{l}\text { Reputation is the perception of external agents about the company on the basis of leadership } \\
\text { behavior strategies, interest in how they are perceived from the outside and corporate culture. }\end{array}$ \\
\hline $\begin{array}{l}\text { Finance and } \\
\text { Accounting }\end{array}$ & $\begin{array}{l}\text { Reputation as an intangible asset ("goodwill") that measures the difference between the } \\
\text { carrying amount of a company and its market value. }\end{array}$ \\
\hline
\end{tabular}

As well as the very concept of reputation for various fields of science is interpreted differently, the methods of assessment differ.

Of interest is the research conducted by Graham Dowling and Peter Roberts [5], in which they tried to trace the relationship between corporate reputation and changes in financial performance. The business reputation in their work was evaluated by company executives and corporate analysts on eight parameters.

They were able to identify the following:

1. A positive corporate reputation increases the length of time to maximize revenue.

2. A positive corporate reputation helps to reduce the time required to achieve financial indicators comparable to the average level.

\section{Methods}

Table 2. Classification of methods for assessing reputation

\begin{tabular}{ccc}
\hline \multirow{2}{*}{ Type } & Evaluation Method & $\begin{array}{c}\text { Methodology developed based on the } \\
\text { method }\end{array}$ \\
\hline \multirow{3}{*}{ Quantitative } & Accounting method & $\begin{array}{c}\text { Goodwill - difference between market and } \\
\text { book value }\end{array}$ \\
\cline { 2 - 3 } & Methods based on financial indicators & $\begin{array}{c}\text { Interbrand, Brand Finance, Brand Valution \& } \\
\text { Analysis }\end{array}$ \\
\cline { 2 - 3 } Quality & Sociological survey methods & Reputation Quotient (RQ) \\
\cline { 2 - 3 } & Expert method & AMAC, Fortune \\
\cline { 2 - 3 } & Comparative method & Fortune 500 \\
\hline
\end{tabular}

Source: Compiled by the author

In Table 1, we present the methods of valuing business reputation that exist in modern practice. Conventionally, they can be divided into two groups: quantitative and qualitative.

Among quantitative methods, the most common is the method of assessing business reputation as goodwill - this is the difference between the market capitalization of the company (the value of all its shares on the stock exchange) and its book value (the amount of net assets calculated according to accounting data).

However, in our opinion, such an assessment cannot be sufficiently reliable in connection with various external factors: for example, the actions of speculators, etc. Moreover, the Russian securities market is not so developed, so the purchase and sale of shares is not a 
direct indicator of reputation. In other words, the fact that the price of shares has dropped or increased does not mean at all that those who want to buy a controlling stake will appear.

At the same time, a quantitative assessment can be divided into determining the actual value of the goodwill based on financial statements and forecasting the future value of goodwill on the basis of extrapolating the actual financial statements (used by the seller to assess the market value of the business if it is sold in the future or by an investor to assess the appropriateness of acquiring a business).

Most of the existing methods for assessing business reputation are of a qualitative nature.

All qualitative methods for assessing reputation can be divided into three groups: expert methods (based on the opinions of experts), social survey method and comparative method.

The first group includes compiling business reputation ratings by independent organizations. The most common and published annually is Fortune Magazine's America's Most Respected Companies (AMAC) project.

Methodologically, reputation ratings are derived by inviting participation from a large group of managers, analysts, and corporate directors. Questionnaires are circulated among potential respondents in the companies to be rated, and "official responses" are obtained. In each questionnaire, raters are asked to respond to eight questions that constitute the "key reputation attributes" on scales from 0 to 10:

1. Quality of management;

2. Quality of products or services;

3. Financial soundness;

4. Ability to attract, develop, and keep talented people;

5. Use of corporate assets;

6. Value as long-term investment;

7. Innovativeness;

8. Community and environmental responsibility.

Thus, after a review of existing methods, we concluded that the internal factors that shape the reputation play a significant role. Therefore, we consider it necessary to consider the tools that shape the reputation.

\section{Results and Discussion}

An increase in the volume of reputation capital is expressed in an increase in public trust in the company, in strengthening a positive image, in the formation of a positive public opinion.

The competitiveness of the organization has a positive trend due to increased prestige, as well as improving the market functioning of the organization and increasing sales. An important factor in building the organization's reputation is the result of interaction not only with the external competitive environment, but also with the internal environment of the enterprise.

The staff is an integral and very strategically important resource of each organization.

Personnel - an object of close and constant attention of managers, as the most important component of the formation of the organization's reputation capital. The foundation for creating a positive reputation for an organization is intellectual resources. When working with staff, management needs to solve the problem of a sense of business solidarity and corporate patriotism. Embed in the minds of employees the prospect of developing their organization. In order to increase the intellectual value of the enterprise, and, consequently, its business image with reputation capital, it is necessary to conduct staff training.

Developing training technologies contribute to staff development, the emergence of extraordinary thinking among employees, the ability to implement new innovative ideas. 
Thanks to this, an internal positive reputation is formed, which directly affects the creation of the external reputation of the company. Developing training helps to create a special professional intelligence among employees, thereby turning them into the intellectual capital of the company. Thus, developmental training helps each employee to gain new abilities, making him more mobile in the labor market.

The company, in turn, receives a unique workforce. An additional effect is the development of the company's reputation capital, which today represents an undeniable competitive advantage.

The solution to this issue can be found in the training technologies for personnel development.

Table 3. Promoting company reputation capital

\begin{tabular}{|c|c|}
\hline Name & $\begin{array}{c}\text { Name Recommended type of training technologies for personnel } \\
\text { development }\end{array}$ \\
\hline Achieving the required category & $\begin{array}{l}\text { Achievement of the required level, categories Increasing the level } \\
\text { of qualification and status of the employee; practical exercises; } \\
\text { workshops; trainings; business games; internships; }\end{array}$ \\
\hline Additional knowledge & $\begin{array}{c}\text { Additional knowledge "Full-time, distance, distance learning } \\
\text { technologies" }\end{array}$ \\
\hline Computer knowledge & Computer Knowledge Automated Learning Technologies \\
\hline The development of related professions & $\begin{array}{l}\text { Mastering related professions Internships; full-time; } \\
\text { intraorganizational; standard training courses }\end{array}$ \\
\hline Certification of workplaces & Certification of jobs Certification \\
\hline $\begin{array}{l}\text { Acquisition by the Manager of knowledge } \\
\text { on the formation of the company's } \\
\text { business image }\end{array}$ & $\begin{array}{l}\text { The acquisition by the head of knowledge on the formation of the } \\
\text { business image of the company Developing; lectures, practical } \\
\text { exercises; workshops; international training }\end{array}$ \\
\hline $\begin{array}{l}\text { Acquisition of knowledge by employees } \\
\text { on the formation of the company's } \\
\text { business image }\end{array}$ & $\begin{array}{l}\text { The acquisition by employees of knowledge on the formation of a } \\
\text { business image of a company. Courses that enhance the status of an } \\
\text { employee; intraorganizational training }\end{array}$ \\
\hline
\end{tabular}

Considering the reputation as an intangible asset of an organization, special attention should be paid to the process of its formation. With the complex and systematic use of reputation building tools, this asset can become the most valuable and at times increase the total cost of the organization.

Reputation tools are a set of tactical measures, united by certain criteria in order to influence the overall perception of the organization. Based on the analysis of bibliographic sources, the following reputation building tools were identified: media relations, a complex of marketing communications, advertising, corporate communication, corporate social responsibility.

Media relations, as a tool for building a reputation, is to inform about the company's activities by sending press texts, responding to media inquiries, and organizing events for journalists. It is important to note that these are tactical events that individually act as tools for creating an image. Specific features of media relations are systematic, systematic and continuous work with the media.

Marketing communications represent a wide range of components, such as branding, direct marketing, etc. However, we note that when building a reputation through marketing communications, it is important to consider the scope of the organization.

Corporate communications include many tactical activities related to the formation and development of corporate culture and internal communications in general. When working with this tool, it is necessary to determine the organizational structure of the company and the type of internal corporate communications, on the basis of which to build further communication with employees to build the reputation of the organization. 
The corporate culture of an enterprise is a combination of beliefs, attitudes, approaches to work, communication methods adopted and observed by most employees during their professional activities in the organization. When using this tool, it is necessary to build communication with employees to build the reputation of the organization based on its organizational structure and type of internal communications.

The company's reputation is formed under the system influence of factors. The company is influenced by the internal and external environment. The formation of reputation capital occurs as a result of the interaction of the internal and external environment of the enterprise, the effectiveness of which determines the size of reputation capital, and its impact on the competitiveness of the organization.

Allocate the tools with which the reputation is formed (Figure 1). These are tactical measures that are aimed at influencing the general perception of the company:

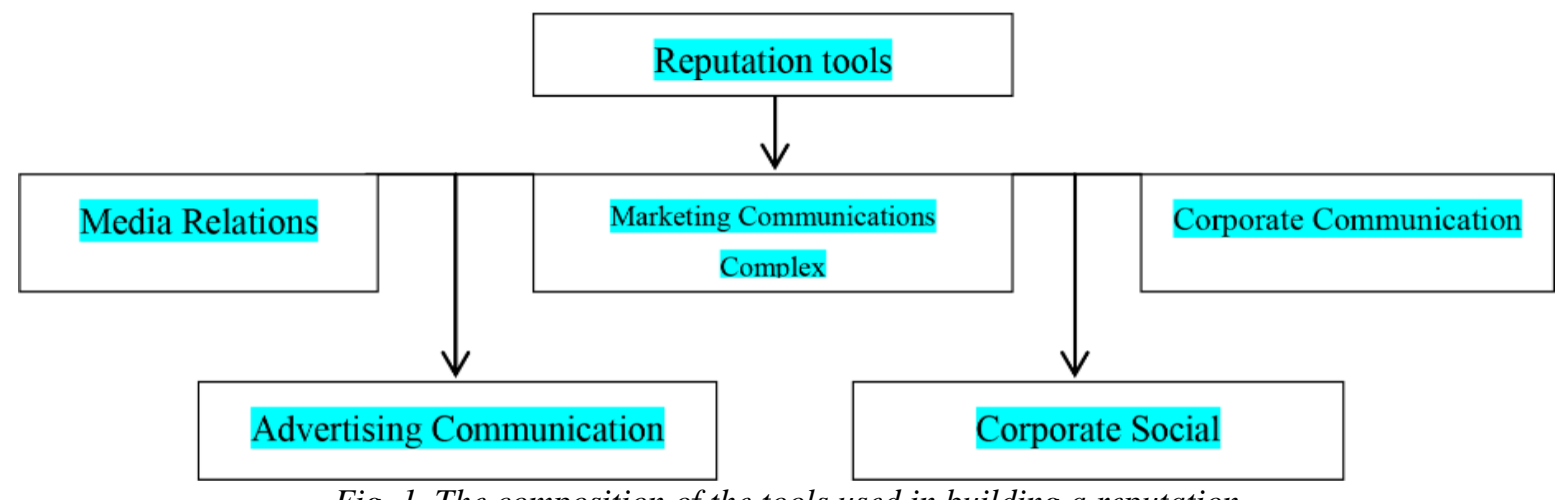

Fig. 1. The composition of the tools used in building a reputation

In accordance with Figure 1, the first tool builds a reputation by sending press texts, replies to the media, and organizing events for journalists. These activities are individually used to create an image.

Allocate the main means of influence in the complex of marketing communications (Figure 2).

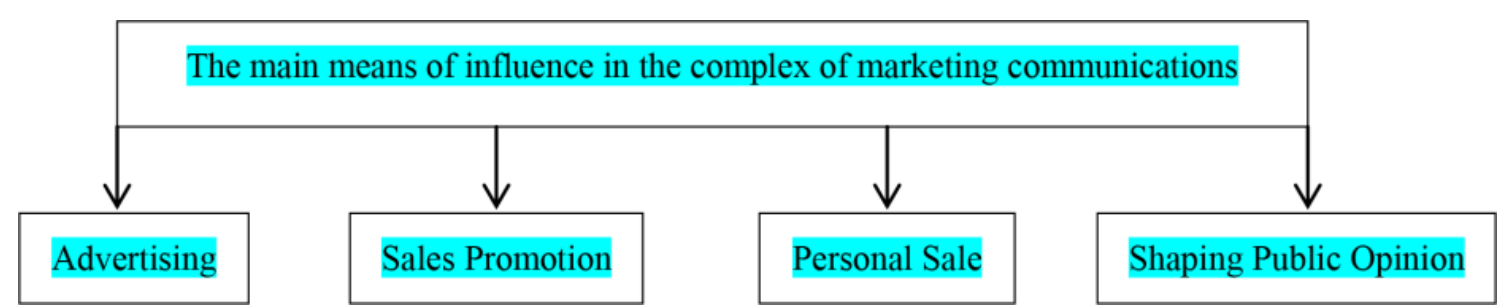

Fig. 2. The main means of influence in the complex marketing communications

Marketing communications also include branding, direct marketing. When using this tool, it is necessary to consider the sphere in which the company operates. Advertising communication builds a reputation through sociocultural transformation.

The main function of advertising follows from its very definition, namely: to interact with the consumer of a product or service, to assist in the formation of demand and stimulate the sale of goods using a large number of different methods and schemes at its disposal. The social function of advertising involves the formation and consolidation of certain consumer values and norms of a given society in the minds of consumers.

Advertising communication, as an independent tool for building a reputation, increases brand awareness and informs about the benefits of the organization's products or services.

Corporate social responsibility is understood as the realization of the company interests by ensuring the social development of its team and the active participation of the organization in 
the development of society. The development of social responsibility is an integral part of entrepreneurial activity.

A socially responsible organization before society has a number of very significant advantages:

1. Improving financial performance;

2. Reduction in operating expenses;

3. Improving the image and reputation of the brand;

4. Increasing sales and customer loyalty;

5. Reducing staff turnover, increasing staff loyalty, increasing employee motivation.

A well-thought-out social policy of the organization, its transparency in relation to environmental protection can positively affect financial performance. In addition to improving financial performance, a well-thought-out social policy helps reduce operating costs.

Recognition by the consumer of a company as socially responsible helps it to remain competitive in the market. The same level of sales and customer loyalty is growing among socially responsible corporations.

Social responsibility is voluntary, based on the ethical principle and internal moral values, and norms.

The internal form of corporate social responsibility involves conducting business practice in relation to its own personnel, everything related to the development of human resources in the enterprise. The appearance of corporate social responsibility involves sponsorship and charity events.

\section{Summary}

In the course of analyzing the assessment methods and tools that create reputation, we can conclude that the assessment of reputation must be considered not only from the point of customers view. Reputation is also assessed from within the company by employees whose assessment of their work organization indirectly creates a reputation through their behavior towards customers and other external economic agents.

Existing methods of reputation assessment, on the one hand, are subjective and do not always sufficiently reflect the real picture, but only the point of view of financially-oriented stakeholders who are generally not interested in issues of social responsibility or working conditions.

On the other hand, their quantitative assessment methods are either focused on evaluating the reputation as a component of the brand, or cannot be sufficiently reliable due to various external factors: for example, the actions of speculators, etc.

Thus, as part of the development of the reputation capital theory, in the future it is necessary to develop more independent quantitative methods for assessing reputation.

\section{Conclusions}

We consider it appropriate to present the whole range of measures for the formation, tactical and strategic management of reputation capital in the form of a reputation strategy.

The ultimate goal of building a reputation strategy is to create a competitive advantage for the enterprise.

Reputation capital is an intangible asset of the enterprise and has the constituent elements: image and reputation. The composition of the tools used in building a reputation is different, but the main tools are a complex of marketing communications and corporate social responsibility of the business. To implement the formation and management of reputation capital, a reputation strategy is carried out. Corporate reputation is most often studied through 
the prism of marketing, so many works on the assessment of business reputation are mainly focused on brands.

Reputation assessment is carried out by specialized companies in order to determine how companies in various countries, for example, the USA, European and Asian, are treated.

The staff of the enterprise plays a significant role in building a business reputation. Each department should be able to contribute to the success of the organization.

\section{Acknowledgements}

The work is performed according to the Russian Government Program of Competitive Growth of Kazan Federal University. The reported study was funded by RFBR, project number 20-31-70001.

\section{REFERENCES}

[1] Covey, S., \& Merrill, R. (2011). The Speed of trust: What changes everything. Moscow: Alpina publisher, p. 25.

[2] Dowling Grahame. (2001). Creating Corporate Reputations Identity, Image and Perfomance. Oxford: Oxford University Press, 299 c.

[3] Fombrun, C. (2007). Essentials of Corporate Communication/Charles Fombrun and Kees van Reel London: Routledge Taylor \& Francis Group, p. 306.

[4] Gafurov, I. R., Safiullin, M. R., \& Akhmetshin, E. M. (2020). Change of the higher education paradigm in the context of digital transformation: From resource management to access control. International Journal of Higher Education 9(3), pp. 71-85. doi:10.5430/ijhe. v9n3p71

[5] Graham Dowling. (2003). Reputation of the firm. Creation, management and evaluation of efficiency. Ed. M.: consulting group "Image-Contact": INFRA-M, p. 368.

[6] Ivanitsky, V. P. (2012). Reputational capital as an element of strategic planning of fashion industry enterprises / V. P. Ivanitsky, M. S. Shcheglov. Bulletin of the South Ural state University. Series: Economics and management, SUSU 2(2), pp. 11-17.

[7] Kamalova, A. A. (2019). Reputation capital of the organization. International Symposium on management, Economics and Finance: sat. scientific articles, pp. 88-90.

[8] Kharlamov, I. (2008). management of reputation capital formation. Kharlamov. Power, 11 [Electronic resource]: URL: http://cyberleninka.ru/article/n/upravlenie-formirovaniem-reputatsionnogo-kapitala.

[9] Safiullin, M.R., Elshin, L.A., \& Kurbangalieva, D.L. (2019). How does reputation economy engagement work to develop financial and economic activity? Opción, Oficina de Publicaciones Científicas de la Facultad Experimental de Ciencias, Universidad del Zulia. Maracaibo - Venezuela, 23(35), pp. 376-392.

[10] Salomatina, E. Yu., \& Ivanov, A. E. (2016). Classification of methods of economic valuation of goodwill. Bulletin of the South Ural state University. Series Economics and management, 3, pp. 26-36.

[11] Sharkov, V. I. (2009). Goodwill Constants. Style, publicity, reputation, image and brand of the company. Moscow: "Dashkov and K", p. 272.

\section{Article history:}

Received 15 September 2020

Accepted 15 November 2020 